\title{
The Toxic Effect of Fluoride and Arsenic on Behaviour and Morphology of Catfish (Clarias batrachus)
}

\author{
G. Sahu*† and V. Kumar** \\ *School of Life Sciences, Pt Ravishankar Shukla University, Raipur, 492010, India \\ **Department of Chemical Engineering, National Institute of Technology, Raipur, 492010, India \\ †Corresponding author: Gamini Sahu; gaminisahu@gmail.com
}

Nat. Env. \& Poll. Tech.

Website: www.neptjournal.com

Received: 20-08-2020

Revised: $09-10-2020$

Accepted: 15-10-2020

Key Words:

Clarias batrachus

Toxicity

Fluoride

Arsenic

\begin{abstract}
In the present study, an attempt has been made to analyze the toxicity of fluoride and arsenic on morphology and behaviour of fish Clarias batrachus. Based on 96 hour LC $_{50}$ values at the $95 \%$ confidence limits of sodium fluoride $(\mathrm{NaF})$ and arsenic trioxide $\left(\mathrm{As}_{2} \mathrm{O}_{3}\right)$ obtained from the preliminary tests, various sub-lethal concentrations of $\mathrm{NaF}$ and $\mathrm{As}_{2} \mathrm{O}_{3}$ were selected for combined toxicity testing. During the experiment, fish were regularly observed for any changes in their external morphology and behaviour. Behavioural changes were observed in terms of air gulping, opercular movement, swimming activity, body position, general activity and food sensitivity. Control fish remained normal throughout the experiment period (96 hour) but erratic, exodus and speedy movements were found in all treated groups. The number of air gulps (per $15 \mathrm{~min}, 24-96$ hour) significantly increased $(P<0.001)$ in the exposed Group I (20 mg. $\left.\mathrm{L}^{-1} \mathrm{As}_{2} \mathrm{O}_{3}\right)$ as compared to control. A significant increase $(\mathrm{P}<0.01)$ in the number of opercular movements (per min for 24-96 hour) was recorded in treatment groups as compared to control. Apparent changes such as excessive mucous secretion, increased body discolouration, loosening of skin and complete loss of skin (head region and fins) were also observed. Skin loss was more intense in fish subjected to Group I.
\end{abstract}

\section{INTRODUCTION}

Although in the present global scenario, humans enjoy a longer and healthier life, nevertheless, rapid industrialization has initiated adverse health effects not only on workforces but also on the common masses (Yassi \& Kjellstrom 1998). As a result, day after day, a large population in the world is under threat of exposure to a variety of toxic chemicals due to heavy contamination of its various ecological systems with various metals, non-metals and other organic and inorganic compounds. One of the biggest contributors to global water crisis (Bibi et al. 2015, Kumar et al. 2020), arsenic and fluoride are such chemicals that are prone to be toxicants and have various deleterious effects on organisms if taken beyond the permissible limit.

Fluorides are naturally released into the environment through the weathering and dissolution of minerals. Besides, various anthropogenic activities are also responsible for fluoride release into the atmosphere. In endemic areas, the most prominent effects in humans are dental, skeletal and non-skeletal fluorosis (Pujara \& Pujara 2003). Arsenic is released into the environment naturally through volcanic action and low temperature volatilization. Industrial processes, such as mining, smelting of non-ferrous metals and burning of fossil fuels contribute to anthropogenic arsenic contamination of air, water and soil (WHO 2001). Very high concentrations of arsenic have been detected in Mexico, Hungary, Chile, Argentina, USA, China, India, Bangladesh, Vietnam, Pakistan etc. (Patel et al. 2005, Jadhav et al. 2015). In India, arsenic occurrences in groundwater of Bengal Delta Plain (i.e. India and Bangladesh) are one of the largest environmental health disasters of the present century. Long term exposure to arsenic leads to adverse multisystem health effects.

Natural and industrial activities contribute to the entry of pollutants into aquatic ecosystems. Contaminated water induces significant changes in structural, physiological and biochemical processes of inhabiting fauna such as fishes (Sivakumar et al. 2014). Behavioural characteristics are sensitive indicators of toxic effects. Since behavioural states are correlated with brain neurotransmitter level and enzyme function, hence behavioural changes induced by toxicant may result in neurological dysfunction. The fluoride acts as an enzyme inhibitor, alters enzymatic activities, interrupting important metabolic processes (glycolysis, protein synthesis etc.) and affects nervous system during fluoride intoxication (Camargo 2003), resulting in negative changes in behaviour, reduced growth and decreased survival of the affected animal 
(Alonso \& Camargo 2009, Aguirre-Sierra et al. 2013). Lethal concentration causes serious acute intoxication in fish before death. Symptoms of fluorosis in fishes, such as increased fluoride level in the blood, lethargy, apathetic behaviour, anorexia, mucus secretion, violent swimming, equilibrium loss, skin darkening, mucus secretion, decreased respiratory rate and finally, death by complete muscular contraction or paralysis have been observed (Camargo 2003, Sahu et al. 2016). Alteration in behaviour pattern induced by sodium fluoride was observed in freshwater fish Puntius sophore (Narwaria \& Saksena 2012) and marked changes in body position, habit, food sensitivity, swimming pattern and opercular movement were noted. In white-clawed Crayfish Austropotamobius pallipes, fluoride increased mortality, but escape response and feeding activity decreased with increasing water fluoride concentration and exposure time (Aguirre-Sierra et al. 2013).

Cholinesterase (ChE) is the most commonly observed indicator of neurological dysfunctions which is inhibited by many pollutants. Study of Tyler \& Allan (2014), have shown reduced acetylcholinesterase (AchE) and choline acetyltransferase (ChAT) activity after arsenic exposure. In another study, female rats exposed to $20 \mathrm{mg} \mathrm{kg}^{-1}$ body weight arsenic for 28 days showed a significant decrease in binding of $3 \mathrm{HQNB}$ to the muscarinic-cholinergic receptor of the hippocampus and frontal cortex. In this brain region, AchE activity reduced after arsenic exposure (Yadav et al. 2011). In freshwater climbing perch, Anabas testudineus (Bloch), exposure of sodium arsenite and mercuric chloride impaired behaviour characteristics, such as rapid opercular movement, erratic swimming, exodus trial and loss of equilibrium etc. (Akter et al. 2008). Bhavani \& Karuppasamy (2014) reported the changes in behaviour parameters as an increase in opercular movement, erratic swimming, equilibrium loss, body dyspigmentation and mucus secretion all over the body of the Zebrafish (Danio rerio) exposed to arsenic trioxide for 96 hours. Aggression increased significantly with arsenic, while the operculum movement decreased nonsignificantly in mosquitofish, Gambusia holbrooki. Presence of algae further aggravates the arsenic effect rather than ameliorating (Magellan et al. 2014). Therefore, in the present study, an attempt has been made to analyze the toxicity of fluoride and arsenic on morphology and behaviour of catfish (Clarias batrachus).

\section{MATERIALS AND METHODS}

Live and healthy fishes (length: $20-25 \mathrm{~cm}$, weight: $80-100 \mathrm{~g}$ ) were procured from nearby fish hatcheries located in Raipur and Rajnandgaon districts of Chhattisgarh, India. The selected fishes were checked \& ensured against injury, infection and disease. During 15 days of acclimatization and experimentation period, fishes were fed with Taiyo fish food at ad libitum. Water was periodically changed every 24 hours to maintain a healthy environment for the fish during acclimation periods. Fishes were maintained at natural photoperiod at ambient temperature. Arsenic trioxide (reagent plus) was purchased from Sigma Aldrich Co., USA, while sodium fluoride (extra pure) was purchased from Himedia Laboratory Pvt. Ltd., Mumbai for assessment of their toxicity towards model fish at the sub-lethal level.

Based on 96 hours $\mathrm{LC}_{50}$ values and at the $95 \%$ confidence limits of sodium fluoride $(\mathrm{NaF})$ and arsenic trioxide $\left(\mathrm{As}_{2} \mathrm{O}_{3}\right)$, obtained from the preliminary tests, various sub-lethal concentrations viz., Group I (20 mg.L $\left.\mathrm{L}^{-1} \mathrm{As}\right)$, Group II (300 mg.L. $\mathrm{L}^{-1} \mathrm{~F}$ ), Group III (100 mg.L $\mathrm{L}^{-1} \mathrm{~F}+10 \mathrm{mg} . \mathrm{L}^{-1} \mathrm{As}$ ) and Group IV (300 mg.L $\mathrm{L}^{-1} \mathrm{~F}+20 \mathrm{mg} . \mathrm{L}^{-1} \mathrm{As}$ ) of sodium fluoride and arsenic trioxide were selected for individual and combined toxicity testing. The control group (Group V) was kept in an aquarium having tap water without the addition of sodium fluoride and arsenic trioxide. Each group stocked 05 fishes per aquarium with $40 \mathrm{~L}$ of water.

\section{Behavioural Studies}

During the experiment days, fish were regularly observed for any changes in their external morphology and behaviour. Observations were made on behavioural aspects, such as air gulping, operculum and swimming movements, general activity and equilibrium, and feeding activity. Opercular movements were noted for per minute and air gulps for 15 min. Morphological changes in fish, viz. skin colour and pigmentation in response to toxicants were also noted.

Statistical analysis was performed by statistical software. One way ANOVA was done in SPSS software (Trial version 16.0).

\section{RESULTS AND DISCUSSION}

Behavioural changes in terms of air gulping, opercular movement, swimming activity, body position, general activity and food sensitivity are depicted in Table 1 (A). The number of air gulps (per $15 \mathrm{~min}, 24-96$ hour) significantly increased $(\mathrm{P}<0.001)$ from $4.67 \pm 0.88$ in the control group to 23.67 \pm 2.03 in the exposed Group I (20 mg.L $\left.\mathrm{L}^{-1} \mathrm{As}\right)$. Significant increase $(\mathrm{P}<0.01)$ in the number of opercular movements (per min for 24-96 hour) was recorded in treatment groups as compared to control. The recorded values ranged from $11.67 \pm 0.32$ in the control group to $43.67 \pm 2.03$ in Group I (20 mg.L. $\mathrm{L}^{-1}$ As) exposed group.

During 96 hour experiment period, treated fishes were very active and restless as compared to control fishes which appeared to be very quiet and relaxed and swam in a 
Table 1(A): Behavioural response of Clarias batrachus in various concentrations of arsenic trioxide and sodium fluoride for a period up to 96 hours.

\begin{tabular}{|c|c|c|c|c|c|}
\hline \multirow[t]{2}{*}{ Parameters } & \multicolumn{5}{|c|}{ Groups with different concentrations of fluoride and arsenic } \\
\hline & Group I & Group II & Group III & Group IV & Group V \\
\hline Air gulping (per $15 \mathrm{~min}$ ) & $14.33 \pm 1.48^{\mathrm{b}}$ & $13.00 \pm 1.15^{\mathrm{a}}$ & $7.67 \pm 1.20^{\mathrm{a}}$ & $13.67 \pm 1.45^{\mathrm{a}}$ & $4.67 \pm 0.88^{\mathrm{b}}$ \\
\hline Opercular movement (per min) & $43.67 \pm 2.03^{b}$ & $40.33 \pm 1.53^{\mathrm{a}}$ & $37.67 \pm 2.52^{\mathrm{a}}$ & $41.33 \pm 1.73^{\mathrm{a}}$ & $31.67 \pm 0.32^{c}$ \\
\hline Swimming movement $(24-96 \mathrm{~h})$ & ES, Ex & ES & ES & ES, Ex & $\mathrm{U}$ \\
\hline Body position $(24-96 \mathrm{~h})$ & $\mathrm{H}$ & $\mathrm{H}, \mathrm{SV}$ & SV & $\mathrm{H}, \mathrm{SV}$ & $\mathrm{B}$ \\
\hline Equilibrium (24-96 h) & EL & EL & EL & EL & $\mathrm{N}$ \\
\hline Food sensitivity (24-96 h) & VL & $\mathrm{L}$ & $\mathrm{L}$ & $\mathrm{L}$ & $\mathrm{N}$ \\
\hline
\end{tabular}

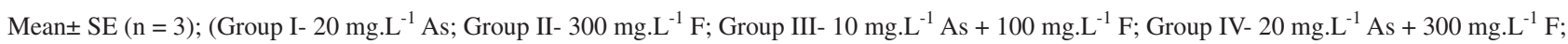
Group V-Control). $U$ uniform, $E S$ erratic and speedy movements, Ex Exodus trials, $H$ hanging mostly, $N$ normal, $E L$ equilibrium lost, $V L$ very low, $L$ low, $B$ at the bottom, SV swimming vertically near the upper surface of the water.

horizontal pattern. Control fish remained normal throughout the experiment period (96 hour) but erratic and speedy movements were found in all treated groups. The test fishes at the concentration of Group I ( $\left.20 \mathrm{mg} . \mathrm{L}^{-1} \mathrm{As}\right)$ and Group IV (20 mg.L $\mathrm{L}^{-1}$ As+300 mg. $\mathrm{L}^{-1} \mathrm{~F}$ ) showed exodus movements and sometimes they tried to hit the wall, jump above the water and move out of the tank. This shows the avoidance behaviour of fishes to the toxicants. Swimming activity of experimental fishes was found to be erratic and speedy. Fish move rapidly with gradual loss of equilibrium, while control fish normally swam horizontally and spent most of the time at the bottom. The fish exposed to arsenic were erratic, speedy with exodus movement, hanging vertically with mouth pointed towards the surface and have a slow response to food. A phenomenon known as nudge and nip has been observed; which involves following and biting other fish. This is a kind of aggressive response.

\section{Morphological Manifestations}

Morphological deformities due to arsenic trioxide and sodium fluoride are shown in Fig. 1(A), (B), (C), (D) and (E). Apparent changes were observed in the external morphology of the fish when exposed to arsenic trioxide and sodium fluoride, but control fish remained normal and healthy throughout the experimental period. Excessive mucous secretion, increased body discolouration, loosening of skin and complete loss of skin from the head region and fins were also observed. Skin loss was more intense in fish subjected to Group I (20 mg. $\left.\mathrm{L}^{-1} \mathrm{As}\right)$. Also, haemorrhages in internal organs and skin including lower lip were seen in exposed fish. Some black spots were also seen in exposed fish.

Alterations in behaviour, such as loss of equilibrium, erratic swimming, hanging, restlessness, and decreased food consumption, increased rate of air gulping and rapid opercular movements observed in the present study depict beyond doubt, a stressful environment due to the presence of toxicants. Mucous formed in ample amounts, forms a layer over the exposed surface of fish thus acting as a barrier to the entry of toxic substances. However, increased mucous secretion also reduces respiratory surface and area for gaseous exchange thereby leading to suffocation of fish which consequently, meets its oxygen demand by increasing air gulping. Arsenic trioxide is generally known to stimulate the peripheral nervous system as a result of increasing energy demand and oxygen utilization. In the same way, opercular movement of fish is increased following the exposure to arsenic and fluoride. Similar behaviour effects of other toxicants have been also seen in previous studies reported by various authors (Bhavani \& Karuppasamy 2014, Kaur \& Dua 2014, Aziz et al. 2015, Sangve 2020). Behavioural effects including erratic swimming, loss of equilibrium and low sensitivity to food, similar to reports by Sahu et al. (2017), Bhavani \& Karuppasamy (2014), were also observed. Erratic swimming and loss of equilibrium observed in the present study may be due to impairment of the nervous system that is responsible for vital activities. In the present study, fish exhibited aggressive response, such as following and attacking other fish, besides, showing speedy movement, hyperactivity, hitting the wall and jumping out from the water, which signifies avoidance reaction in response to the toxicants. These activities may be due to the inactivation of acetylcholinesterase, an enzyme critical for the metabolism of acetylcholine. Arsenic and fluoride are reported to decrease the activity of acetylcholinesterase in rats (Tolins et al. 2014, Bharti \& Srivashtava 2011). Free radical production is the potential mechanism of action of fluoride and arsenic-induced neurotoxicity (Shanmugam et al. 2018, Akter et al. 2017). Arsenic induces oxidative stress through overproduction of reactive oxygen species, which leads to improper brain development and associated behaviours (Sau et al. 2020, Flora et al. 2012). However, fluoride can inhibit the activity of free radical scavenging or antioxidant enzymes (Shanmugam et al. 2018).

Food consumption is the most sensitive end point because 


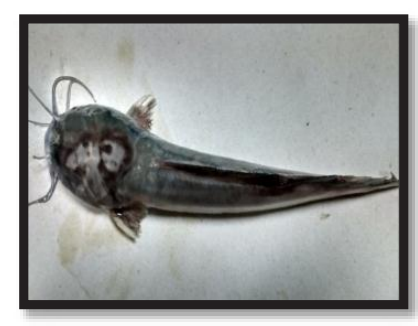

(A) Group I (20 mg.L-1 As)

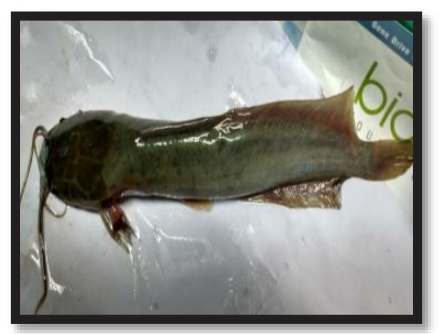

(C) Group III (10 mg.L $\left.\mathrm{L}^{-1} \mathrm{As}+100 \mathrm{mg} \cdot \mathrm{L}^{-1} \mathrm{~F}\right)$

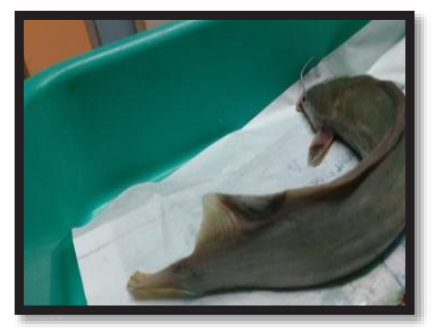

(B) Group II (300 mg. $\left.\mathrm{L}^{-1} \mathrm{~F}\right)$

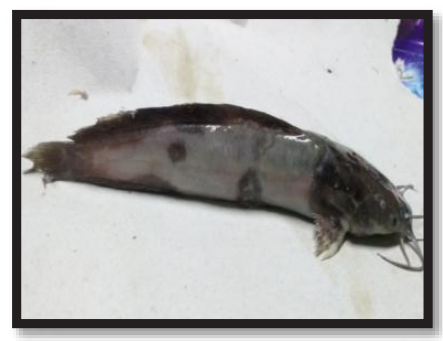

(D) Group IV (20 mg. $\left.\cdot \mathrm{L}^{-1} \mathrm{As}+300 \mathrm{mg} \cdot \mathrm{L}^{-1} \mathrm{~F}\right)$

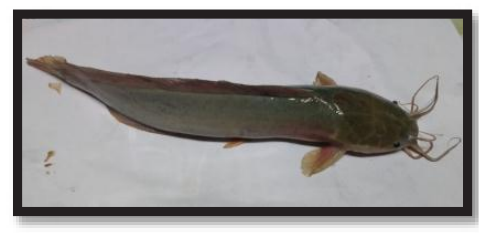

(E) Group V (Control)

Fig. 1: Morphological deformities.

negative changes in behaviour increase the rate of mortality in affected fish and other animals (Anguirre-Sierra et al. 2013). Similar findings were reported by Yallappa \& Nuzhat (2017), after exposing Austropotamobius pallipes to fluoride; their mean daily food consumption was decreased with increasing water fluoride concentration and exposing Cyprinus carpio to cadmium chloride and found that food consumption was affected and reduced over time. In some extent decrease in food uptake under toxicant stress environment is beneficial to lower the energy cost of digestion.

Morphological deformities were shown in the form of dullness in body colour, loosening of skin and complete loss of skin in head and fin. Similar observations were reported in previous studies on fish morphology (Devi \& Mishra 2013, Anita et al. 2010). Aziz et al. (2015) reported darkening of skin and increased mucus secretion, gasping for breath, inability to swim after 14 days of sodium fluoride exposure and finally death after long term exposure. Haemorrhage in internal organs and lower lip was observed in exposed fish. Similar damage was reported in Channa punctatus due to zinc and municipal wastewater toxicity and in Labio rohita and Cirrhinus mrigala exposed to tannery industry effluent and dyeing industry effluent respectively (Walia et al. 2013, Kaur et al. 2013). Morphological changes in fish were more intense in the arsenic treated group as compared to fluoride treated group, since heavy metals like arsenic, especially bind with keratin rich tissues (skin, hair and nails) and get deposited in skin tissues.

\section{CONCLUSION}

Behavioural and morphological alteration in Clarias batrachus under the influence of fluoride and arsenic can 
be used as a sensitive biological marker to monitor aquatic contamination. From the present study, it becomes clear that arsenic and fluoride create a stressful environment by influencing the nervous system and by reducing the activity of some enzymes (AchE, ChAT). Even at very low concentration of arsenic trioxide seemed to be comparatively more effective in causing behavioural alteration and stress than sodium fluoride. From the result of the present investigation, we can say that the behavioural effect act as a 'first-line indicator' for evaluation of toxicity. Furthermore, research is needed in this field to better understand the mechanism of arsenic and fluoride combined toxicity.

\section{REFERENCES}

Aguirre-Sierra, A., Bacchetti-De Gregoris, T., Berná, T., Salas, J.J., Aragón, C. and Esteve-Núñez, A. 2016. Microbial electrochemical systems outperform fixed-bed biofilters in cleaning up urban wastewater. Enviro. Sci. Water Res. Techno., 2: 984-993.

Aktar, S., Jahan, M., Alam, S., Mohanto, N.C., Arefin, A., Rahman, A. Haque, A., Himeno, S., Hossain, K. and Saud, Z.A. 2017. Individual and combined effects of arsenic and lead on behavioral and biochemical changes in mice. Biol. Trace. Elem. Res., 177: 288-296.

Alonso, A. and Camargo, J.A. 2009. Long-term effects of ammonia on the behavioral activity of the aquatic snail Potamopyrgus antipodarum (Hydrobiidae, Mollusa). Arch. Environ. Contam. Toxicol., 56: 796-802.

Anita, T.S., Shobha, K. and Tilak, K.S. 2010. A study on acute toxicity, oxygen consumption and behavioural changes in the three major Carp, Lebio rohita, Catla catla (ham) Cirrhinus mrigala (ham.) exposed to fenvalerate. Biores. Bull., 1: 33-40.

Aziz, F., Azmat, R. and Jabeen, F. 2015. Fluoride Toxicity on behavioral and morphological variations in freshwater fish Notopterus notopterus (Pallas). Int. J. Adv. Res., 3: 1223-1227.

Bharti, V.K. and Srivastava, R.S. 2011. Effect of pineal proteins at different dose level on fluoride-induced changes in plasma biochemicals and blood antioxidants enzymes in rats. Biol. Trace Elem. Res., 141: 1-3.

Bhavani, K. and Karuppasamy, R. 2014. acute toxicity bioassay and behavioural changes on zebra fish, Danio rerio (Hamilton) under arsenic trioxide. Int. J. Mod. Res Rev., 2: 40-46.

Bibi, S., Farooqi, A., Hussain, K. and Haider, N. 2015. Evaluation of industrial based adsorbents for simultaneous removal of arsenic and fluoride from drinking water. J. Cleaner Prod., 87: 882-896.

Camargo, J.A. 2003. Fluoride toxicity to aquatic organisms: A review. Chemosphere, 50: 251-264.

Devi, Y. and Mishra, A. 2013. Study of behavioural and morphological anomalies of fry fish of freshwater teleost, Channa punctatus under chlorpyrifos intoxication. Int. J. Pharma. Bio. Sci., 4: 865-874.

Flora, S.J.S., Mittal, M., Pachauri, V. and Dwivedi, N. 2012. A possible mechanism for combined arsenic and fluoride induced cellular and DNA damage in mice. Metallomics, 4: 78-90.

Jadhav, S.V., Bringas, E., Yadav, G.D., Rathod, V.K., Ortiz, I. and Marathe, K.V. 2015. Arsenic and fluoride contaminated groundwaters: A review of current technologies for contaminants removal. J. Environ. Manage., 162: 306-325.

Kaur, R. and Dua, A. 2014. $96 \mathrm{~h} \mathrm{LC}_{50}$, behavioural alterations and histopathological effects due to wastewater toxicity in a freshwater fish
Channa punctatus. Environ. Sci. Pollut. Res., 22: 5100-5110.

Kumar, V., Pandey, N., Dharmadhikari, S. and Ghosh, P. 2020. Degradation of mixed dye via heterogeneous Fenton process: Studies of calcination, toxicity evaluation, and kinetics. Water Environ. Res., 92: 211-221.

Magellan, K., Barral-Fraga, L., Rovira, M., Srean, P., Urrea, G., GarcíaBerthou, E. and Guasch, H. 2014. Behavioural and physical effects of arsenic exposure in fish are aggravated by aquatic algae. Aquatic toxicology, 156: 116-124.

Narwaria, Y.S. and Saksena, D.N. 2012. Acute toxicity bioassay and behavioural responses induced by sodium fluoride in freshwater fish Puntius sophore (Bloch). Fluoride, 45(1): 7-12.

Patel, K.S., Shrivas, K., Brandt, R., Jakubowski, N., Corns, W. and Hoffmann, P. 2005. Arsenic contamination in water, soil, sediment and rice of central India. Environ. Geochem. Health., 27: 131-145.

Pujara, N. and Pujara, P. 2003. Fluoride toxicity- A systematic review. Int. J. Sci. and Res., 4: 2319-7064.

Sahu G. and Poddar A. N. 2016. Effect of sodium fluoride on total protein and albumin globulin ratio of Clarias batrachus (Linn.) 1758. J. Ravishankar Uni., 29 (2\&3): 11-16.

Sahu, S., Pervez, S. and Poddar, A. N. 2017. Combined toxicity and bioconcentration of fluoride and arsenic in African catfish Clarias gariepinus (Burchell, 1822). Int. J. Environ. Agri. Biotechnol., 2: 967-976.

Sangve, K.B. 2020. Behavioural study of freshwater fishes Rasbora daniconius and Puntius saphore exposed to sodium fluoride. Int. Res. J. Sci. Eng., 8: 59-64.

Sau, S., Sathua, K. B. and Flora, S.J.S. 2020. MiADMSA minimizes arsenic induced bone degeneration in Sprague Dawley rats. Emerg. Contam., 6: 204-211.

Shanmugam, T., Abdulla, S., Yakulasamy, V., Selvaraj, M. and Mathan, R. 2018. Mechanism underlying the neurotoxicity induced by sodium fluoride and its reversal by epigallocatechin gallate in the rat hippocampus: Involvement of $\mathrm{NrF} 2 / \mathrm{Keap}-1$ signaling pathway. JoBAZ, 79: 17.

Sivakumar, P., Kanagappan, M., Manohar, S. and Das, S. 2014. Toxicity evaluation and behavioural responses of Danio rerio exposed to raw tannery effluent. J. Eentomol. Zool. Stud., 2: 288-291.

Tolins, M., Ruchirawat, M. and Landrigan, P. 2014. The developmental neurotoxicity of arsenic: Cognitive and behavioral consequences of early life exposure. Ann. Global Health, 80: 303-314.

Tyler, C. R. and Allan, A. M. 2014. The effects of arsenic exposure on neurological and cognitive dysfunction in human and rodent studies: A review. Curr. Environ. Health Rep., 2: 132-147.

Walia, G.K., Handa, D., Kaur, H. and Kalotra, R. 2013. Behavioral and morphological changes in a freshwater fish, Labeo rohita exposed to tannery industry effluent. Zool., 2: 514-516.

WHO 2001. Environmental Health Criteria 224- Arsenic and Arsenic Compounds. International Programme on Chemical Safety, Geneva, Switzerland.

Yadav, R.S., Chandravanshi, L.P., Shukla, R.K., Sankhwar, M.L., Ansari, R.W., Shukla, P.K., Pant, A.B., and Khanna, V.K. 2011. Neuroprotective efficacy of curcumin in arsenic induced cholinergic dysfunctions in rats. Neurotoxicol., 32: 760-768.

Yallappa, S. and Asiya Nuzhat, F.B. 2017. Toxic effect of biochemical and morphological changes on carp (Cyprinus carpio) exposed to cadmium chloride. Int. J. Zool. Stud., 2: 222-228.

Yassi, A. and Kjellstrom, T. 1998. Environmental health hazards. In: Stellman, J.M. (Ed.), Encyclopedia of Occupational Health and Safety 1, International Labour Organization, Geneva. 